\title{
Coronavirus (Covid-19) and Stock Market: Empirical Analysis with Panel Data Approach
}

\author{
Emre Esat Topaloglu ${ }^{1}$, Ilhan Ege ${ }^{2} \&$ Erol Koycu ${ }^{3}$ \\ ${ }^{1}$ Faculty of Economics and Administrative Sciences, Sirnak University, Sirnak, Turkey \\ ${ }^{2}$ Faculty of Economics and Administrative Sciences, Mersin University, Mersin, Turkey \\ ${ }^{3}$ Faculty of Economics and Administrative Sciences, Sirnak University, Sirnak, Turkey \\ Correspondence: Emre Esat Topaloglu, Faculty of Economics and Administrative Sciences, Sirnak University, \\ Sirnak, Mehmet Emin Acar Campus, Turkey. Tel: 090-486-216-4008. E-mail: emresatopal@ hotmail.com
}

Received: December 22, 2020

Accepted: January 8, 2021

Online Published: February 10, 2021

doi:10.5539/ijef.v13n3p31

URL: https://doi.org/10.5539/ijef.v13n3p31

\begin{abstract}
In this study, the relationship between the pandemic and the stock market range of the dates 17-03-2020 and 14-04-2020, when the COVID-19 pandemic was most intense, was examined by panel data analysis method. In this study conducted for Turkey and Belgium, Germany, France, Italy, Spain, United Kingdom, United States, China and Netherland countries where the COVID-19 pandemic is most common, COVID-19 data is based on the total number of cases and the total number of deaths, while stock market data is based on important stock indexes of countries. The results of the study, while a negative relationship was found between total number of cases and the stock market, a positive relationship was found between total number of death and the stock market. This is an indication that market investors are closely monitoring the number of COVID-19 cases, and that the number of cases described significantly affects stock market investments.
\end{abstract}

Keywords: COVID-19, stock market, panel data analysis

Jel: C33, D53, I10.

\section{Introduction}

Coronavirus, also known as COVID-19, was first reported by the World Health Organization (WHO) on January 21,2020 . This first report published stated that symptoms of the disease were seen from unknown causes in Wuhan, Hubei region of China on December 31, 2019, and this condition was reported to the World Health Organization office located in China. The same report stated that between December 31, 2020, and January 3, 2020, 44 people showed signs of disease of unknown cause and a new type of Coronavirus was identified by the Chinese authorities on January 7, 2020 (WHO, Novel Coronavirus Situation Report - 1, January 21, 2020). The world has started to fight the new type of coronavirus that emerged from this date. Coronavirus spread to other countries shortly after its appearance in China. Due to coronavirus January 13, 2020, in Thailand 2 people, January 15, 2020, in Japan 1 person, January 20, 2020, in Korea 1 person has been diagnosed with the disease (WHO). Coronavirus has been started to spread rapidly throughout the world due to the failure of other countries to take the necessary precautions. Seen January 23, 2020, in the United States, January 24, 2020, in Singapore, January 25, 2020, in France and Austria (WHO). Coronavirus has been seen in so many different geographies in such a short period, Coronavirus is now a disease that not only China but also the whole world has to fight. By the WHO the January 30, 2020 declaration of a state of emergency and the announcement of coronavirus as an epidemic on March 11, 2020, demonstrate the severity of the disease. Taking decisions such as curfews, countries declaring quarantines in certain regions and closing the borders of the country are other important developments that show the seriousness of the incident.

There are many studies about previous epidemics SARS (2003) and Ebola (2014). These studies result in show that negatively affects economies, causes extreme volatility in financial markets, and investors sell stocks they own in a mood of panic. The researchs are presented in the literature section. As with previous epidemics, economies were negatively affected by the coronavirus epidemic disease. The closure of workplaces, the rise in unemployment rates and the downward revision of countries' growth rates are all indicators of economic cooling. Fluctuations in financial markets began to occur with the expectation that firm profitability would decline and economies would cool due to people not being able to do business. During this time, it is seen that investors gave 
up their investments in panic and started selling their risky assets. The Federal Reserve System (USA), the largest central bank in the world, has announced that it will lower interest rates and increase its balance sheet due to the economic cooling (federalreserve.org). This is an indication that his economy is cooling. This is because central banks are cutting interest rates and giving money to the market are practices to stimulate economies. Many countries of the world revised interest rates downwards and decided to increase their balance sheets. This increased the tension of investors trading in the markets and accelerated sales in the financial markets. Investors panic and market contagion effect (Masson, 1998) has led to fluctuations in financial markets in almost every part of the world. It is now a known fact that coronavirus affects economies negatively, which in turn directly causes volatility in financial markets.

A graphic is presented below to better see the volatility in financial markets. This chart shows the MSCI Emerging Market Index and MSCI World Index performances with weekly data between December 30, 2019, and April 15, 2020. The MSCI Emerging Market Index shows the financial markets average of 26 developing countries, while the MSCI World Index shows the financial markets average of 23 developed countries.

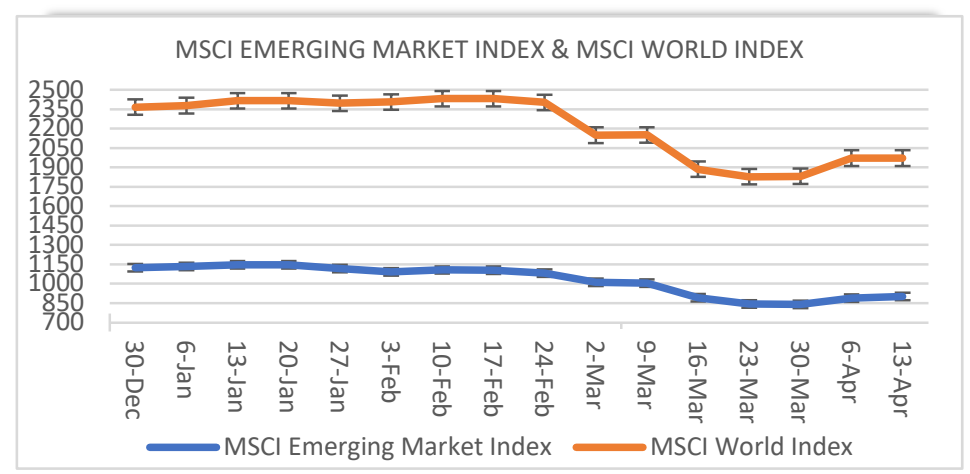

Figure 1. MSCI emerging market index \& MSCI world index

When the data contained in the graphic is examined seen that the highest value for the MSCI Emerging Market Index is 1147.22 March 30 and the lowest value is 840.22 on January 20 . The percentage change is about $36 \%$. When the MSCI World Index data is examined with the same method seen that the highest value is 2431,03 February 10 whereas the lowest value is 1827.74 March 23 . The percentage change is about $33 \%$. So it can be said that volatility in the $30-40 \%$ range is seen in the leading developed and emerging markets.

This study is based on coronavirus disease reports published by WHO. Between December 31, 2019, and April 15,2020 , for the 10 countries with the highest number of cases of coronavirus examined with the panel data analysis method relationship between total number of coronavirus cases and total number of deaths and stock markets return.

\section{Literature Review}

Many studies are analyzed the impact of epidemics on the economy and markets. In particular, the impact of the SARS outbreak in Taiwan in 2003 on the economy has attracted the attention of many researchers. Marley et al. (2004) stated that the epidemic of SARS caused millions of dollars for the American economy. It was found by Hai et al. (2004) that SARS disease had a significantly negative effect on China economy. Ebola virus disease (EVD), another epidemic, first appeared in Africa in 2014. As with the SARS outbreak, there have been studies that the Ebola outbreak has adversely affected the economy. The study by Adegun (2014) concluded that the Ebola outbreak slowed the economy and reduced trade in West African countries. Bowles et al. (2015) their study found that the Ebola outbreak adversely affected the economy and caused people to lose their jobs. The Ebola outbreak remains somewhat more economically limited than the SARS outbreak, and negatively affects African countries where it was first seen.

But this is not true for financial markets. It is known that negative news, such as the resulting political crisis, war and epidemic, has unsettled investors and increased volatility in financial markets. Indeed, this is true within SARS and Ebola epidemics. The study by Loh (2006) found that the SARS outbreak harmed airlines and continued to impact on airlines even after the outbreak was over. Another sector affected by epidemics is tourism companies. Chen et al. (2007) found that the SARS epidemic disease most affected the stocks operating in the tourism sector and that tourism company in the Taiwan Stock Market depreciated by about 50 percent in April and May 2003. The study by Kongoley (2015) stated that the Ebola epidemic disease indirectly and negatively affects many sectors, especially tourism and airline companies. Another study examining the impact of the Ebola 
epidemic disease on financial markets was studied by Marinc (2016). The study found that the Ebola epidemic affected United States stock prices negatively, making investors more susceptible to negative news flow. Gupta et al. (2004) stated that there are economically positive aspects of epidemics and that being quarantined due to epidemics increases people's savings. Studies on SARS (2003) and EVD (2014) have been found that trade declined economically, economies shrunk and stock markets collapsed.

Considering these studies, it seems normal for people to be concerned about the COVID-19 outbreak, to be afraid that they will lose their jobs, and that state administrators are nervous about their country. April 15, 2020, the WHO report stated that 1 million 914 thousand 916 people worldwide had coronavirus and 123 thousand 10 people had died from this outbreak (WHO, COVID-19 Situation Report, 2020, p. 86). It seems that this issue has already attracted the attention of researchers. The study by Fernandes (2020) stated that coronavirus would negatively affect the world gross domestic product for every month that it could not be prevented. The IMF reported that there is an economic uncertainty due to Coronavirus and that the world economy will shrink by -3 percent in 2020 (IMF, World Economic Outlook, 2020, p. 1).

Because of the Coronavirus outbreak, investors seem to avoid risk. The US Dow Jones index, the UK FTSE index, the Germany DAX Index, the France CAC 40 index and others, the world's leading markets, saw daily drops of $10-15 \%$. It has been stated in the study by Ramelli and Wagner (2020) that investor concerns have increased due to Coronavirus and that prices have fallen in stock markets. Coronavirus has increased volatility in the China market Corbet et al. (2020), high volatility in US markets has caused Baker et al. (2020), negatively affects the stock markets of France and Italy and increases volatility Onali (2020) and Zeren and Hizarc1 (2020) found that there is a positive relationship between the number of coronavirus deaths and stock market volatility.

Coronavirus is expected to affect both the global economy and the economies of the country, as well as the previous SARS and Ebola epidemics. In the largest economy of the world, America, the report announced by the Ministry of Labor announced that 6 million 600 thousand people applied for unemployment insurance in a week between 28 March 2020 and 4 April 2020 (US Department of Labor, Unemployment Insurance Weekly Claims, April 9, 2020). The same institution announced that 5 million 245 thousand people applied for unemployment insurance between April 42020 and April 11, 2020 (US Department of Labor, 2020).

Not only just in America but also all over the world, most people have closed their businesses and are quarantined in their homes. Another important report was published by the Organization for Economic Co-operation and Development (OECD). OECD, its economic outlook report about coronavirus, predicted that the world economy is at risk and the global economy will shrink by -0.5 percent (OECD, 2020). The world's leading credit rating agencies have also published reports on the risk situation of countries in the face of this extraordinary situation. Fitch Ratings, one of the important credit rating agencies, has been downgraded its UK credit rating from AA to AA- (Fitch Ratings, 2020). Moody's, another important credit rating agency, appears to have been downgraded its South African credit rating from Baa3 to Ba1 in the report published on March 27, 2020 (Moody's Rating, 2020). When the reports published by the OECD and IMF and the data released by the United States are examined, it is seen that there will be a contraction in the economy and that the impact of the coronavirus outbreak will be great. This situation is supported by literature studies.

\section{Method}

In this study, the impact of the COVID-19 epidemic on the stock market in Turkey and the 9 most common countries in the range of 17-03-2020 to 14-04-2020 was investigated using the panel data analysis method. In this direction, analysis results on cross-section dependence and homogeneity tests conducted on a panel basis, tests for estimating panel data models, heteroscedasticity and autocorrelation tests and prediction results were included. In the study, the total number of cases and the total number of deaths in countries were taken into account as independent variables, the important indices of the stock market of countries were taken into account as a dependent variable. A panel regression model was set to determine the relationship between the coronavirus and stock markets. The model is presented below:

$$
\text { Stockmarketreturn }_{i t}=\alpha_{i t}+B_{2 i t} \text { totalcases }_{i t}+\beta_{3 i t} \text { totaldeath }_{i t}+\varepsilon_{i t}+\lambda_{t}
$$

This model was built on the stock market return, which is the dependent variable and total cases and total deaths which are independent variable. In the model, $\mathrm{i}=1,2,3, \ldots . \mathrm{N}$ cross-sectional units, $\mathrm{t}=1,2,3, \ldots \ldots \mathrm{T}$ is the time dimension, $\beta$ is the slope coefficient of explanatory variables and $\varepsilon$ is expressed as the panel error term.

\section{Data and Empirical Findings}

The study focused on Turkey and 9 countries where the epidemic was most common. The table showing the names of these countries and the stock markets indices is presented below; 
Table 1. Countries and stock markets

\begin{tabular}{cll}
\hline No & Country & Stock Market \\
\hline 1 & Belgium & BEL 20 (BFX) \\
2 & Germany & DAX (GDAXI) DAX (GDAXI) \\
3 & France & CAC 40 (FCHI) \\
4 & Italy & FTSE MIB (FTMIB) \\
5 & Spain & IBEX35 \\
6 & United Kingdom & FTSE 100 (FTSE) \\
7 & United States & Dow Jones Industrial Average (DJI) \\
8 & China & Shanghai Composite (SSEC) \\
9 & Turkey & BIST 100 (XU100) \\
10 & Netherland & AEX (AEX) \\
\hline
\end{tabular}

Source: www.investing.com, date of access: 01.07.2020.

From 17-03-2020 to 14-04-2020 Turkey and the 9 countries where the outbreak was most common, the table showing the total number of cases and the total number of deaths is presented below;

Table 2. Total cases and total deaths

\begin{tabular}{ccccccccccc}
\hline \multicolumn{10}{c}{ Total Cases } \\
\hline Date & Belgium & Germany & France & Italy & Spain & United Kingdom & United States & China & Turkey & Netherland \\
\hline $3 / 17 / 2020$ & 1243 & 9367 & 7730 & 31506 & 11826 & 1950 & 6346 & 80894 & 98 & 1705 \\
$3 / 18 / 2020$ & 1486 & 12327 & 9134 & 35713 & 14769 & 2626 & 9296 & 80928 & 191 & 2051 \\
$3 / 19 / 2020$ & 1795 & 15320 & 10995 & 41035 & 18077 & 3269 & 13865 & 80967 & 359 & 2460 \\
$3 / 20 / 2020$ & 2257 & 19848 & 12612 & 47021 & 21571 & 3983 & 19497 & 81008 & 670 & 2994 \\
$3 / 23 / 2020$ & 3743 & 29056 & 19856 & 63927 & 35136 & 6650 & 44056 & 81171 & 1529 & 4749 \\
$3 / 24 / 2020$ & 4269 & 32991 & 22304 & 69176 & 42058 & 8077 & 55222 & 81218 & 1872 & 5560 \\
$3 / 25 / 2020$ & 4937 & 37323 & 25233 & 74386 & 49515 & 9529 & 68673 & 81285 & 2433 & 6412 \\
$3 / 26 / 2020$ & 6235 & 43938 & 29155 & 80589 & 57786 & 11658 & 86061 & 81340 & 3629 & 7431 \\
$3 / 27 / 2020$ & 7284 & 50871 & 32964 & 86498 & 65719 & 14543 & 104804 & 81394 & 5698 & 8603 \\
$3 / 30 / 2020$ & 11899 & 66885 & 44550 & 101739 & 87956 & 22141 & 165053 & 81518 & 10827 & 11750 \\
$3 / 31 / 2020$ & 12775 & 71808 & 52128 & 105792 & 95923 & 25150 & 189967 & 81554 & 13531 & 12595 \\
$4 / 1 / 2020$ & 13964 & 77981 & 56989 & 110574 & 104118 & 29474 & 216622 & 81589 & 15679 & 13614 \\
$4 / 2 / 2020$ & 15348 & 84794 & 59105 & 115242 & 112065 & 33718 & 246729 & 81620 & 18135 & 14697 \\
$4 / 7 / 2020$ & 22194 & 107663 & 109069 & 135586 & 141942 & 55242 & 403521 & 81802 & 34109 & 19580 \\
$4 / 8 / 2020$ & 23403 & 113296 & 112950 & 139422 & 148220 & 60733 & 435518 & 81865 & 38226 & 20549 \\
$4 / 9 / 2020$ & 24983 & 118235 & 117749 & 143626 & 153222 & 65077 & 469124 & 81907 & 42282 & 21762 \\
$4 / 14 / 2020$ & 31119 & 132210 & 143303 & 162488 & 174060 & 93873 & 613886 & 82295 & 65111 & 27419 \\
\hline
\end{tabular}

Table 2. Total cases and total deaths (Continuation of Table 1)

\begin{tabular}{ccccccccccc}
\hline \multicolumn{10}{c}{ Dotal Deaths } \\
\hline Date & Belgium & Germany & France & Italy & Spain & United Kingdom & United States & China & Turkey & Netherland \\
\hline $3 / 17 / 2020$ & 10 & 26 & 175 & 2503 & 533 & 71 & 110 & 3237 & 1 & 43 \\
$3 / 18 / 2020$ & 14 & 28 & 264 & 2978 & 638 & 104 & 150 & 3245 & 2 & 58 \\
$3 / 19 / 2020$ & 21 & 44 & 372 & 3405 & 831 & 144 & 206 & 3248 & 4 & 76 \\
$3 / 20 / 2020$ & 37 & 68 & 450 & 4032 & 1093 & 177 & 255 & 3255 & 9 & 106 \\
$3 / 23 / 2020$ & 88 & 123 & 860 & 6077 & 2311 & 335 & 556 & 3277 & 37 & 213 \\
$3 / 24 / 2020$ & 122 & 159 & 1100 & 6820 & 2991 & 422 & 781 & 3281 & 44 & 276 \\
$3 / 25 / 2020$ & 178 & 206 & 1331 & 7503 & 3647 & 463 & 1028 & 3287 & 59 & 356 \\
$3 / 26 / 2020$ & 220 & 267 & 1696 & 8215 & 4365 & 578 & 1296 & 3292 & 75 & 434 \\
$3 / 27 / 2020$ & 289 & 351 & 1995 & 9134 & 5138 & 759 & 1697 & 3295 & 92 & 546 \\
$3 / 30 / 2020$ & 513 & 645 & 3024 & 11591 & 7716 & 1408 & 3150 & 3305 & 168 & 864 \\
$3 / 31 / 2020$ & 705 & 775 & 3523 & 12428 & 8464 & 1789 & 4064 & 3312 & 214 & 1039 \\
$4 / 1 / 2020$ & 828 & 931 & 4032 & 13155 & 9387 & 2352 & 5114 & 3318 & 277 & 1173 \\
$4 / 2 / 2020$ & 1011 & 1107 & 5387 & 13915 & 10348 & 2921 & 6088 & 3322 & 356 & 1339 \\
$4 / 7 / 2020$ & 2035 & 2016 & 10328 & 17127 & 14045 & 6159 & 12868 & 3333 & 725 & 2101 \\
$4 / 8 / 2020$ & 2240 & 2349 & 10869 & 17669 & 14792 & 7097 & 14811 & 3335 & 812 & 2248 \\
$4 / 9 / 2020$ & 2523 & 2607 & 12210 & 18279 & 15447 & 7978 & 16712 & 3336 & 908 & 2396 \\
$4 / 14 / 2020$ & 4157 & 3495 & 15729 & 21067 & 18255 & 12107 & 26047 & 3342 & 1403 & 2945 \\
\hline
\end{tabular}

Source: www.worldometers.info, date of access: 01.07.2020. 
A table showing the results of the panel data analysis, which analyzes the effects of the total number of cases and the total number of deaths on the share market in Turkey and the 9 countries where the most common are presented below;

Table 3. Descriptive statistics and results of correlation analysis, VIF

\begin{tabular}{lc}
\hline Total Death-Mean & 3627.341 \\
Total Cases-Mean & 61032.67 \\
Stock Market-Mean & 0.008625 \\
Total Death-Skewness & 1.952738 \\
Total Cases-Skewness & 3.619177 \\
Stock Market-Skewness & 0.303344 \\
Total Death-Kurtosis & 6.440499 \\
Total Cases-Kurtosis & 20.41099 \\
Stock Market-Kurtosis & 3.431856 \\
Total Death-Jarque-Bera & $191.8860\left(0.000^{* * *}\right)$ \\
Total Cases-Jarque-Bera & $2518.383\left(0.000^{* * *}\right)$ \\
Stock Market-Jarque-Bera & $3.928210(0.140)$ \\
Total Death-Std. Dev & 5026.033 \\
Total Cases-Std. Dev & 82392.62 \\
Stock Market-Std. Dev & 0.032720 \\
Total Death-Centered VIF & 5.654816 \\
Total Cases-Centered VIF & 5.654816 \\
Total Death and Total Cases-Correlation & 0.885972 \\
Total Death and Stock Market-Correlation & -0.029243 \\
Total Cases and Stock Market-Correlation & -0.026266 \\
\hline
\end{tabular}

In comparison with descriptive statistics results, while the total number of cases and the total number of deaths series were normally distributed, the stock market series were not normally distributed. The correlation between the total number of cases and the total number of deaths was determined as high as 0.88 , as expected. The fact that the VIF values of the independent variables take a value of 5.65 supports that there is no multicollinearity problem in the series.

Table 4. The results of cross-sectional dependence and Homogeneity tests

\begin{tabular}{ll}
\hline Total Cases-Pesaran $2004 \mathrm{CDlm}$ & $6.810\left(0.000^{* * * *}\right)$ \\
Total Death-Pesaran $2004 \mathrm{CDlm}$ & $7.002\left(0.000^{* * *}\right)$ \\
Stock Market-Pesaran 2004 CDlm & $0.256(0.399)$ \\
Total Cases-PUY, 2008 LMadj & $18.154\left(0.000^{* * * *}\right)$ \\
Total Death-PUY, 2008 LMadj & $13.043\left(0.000^{* * *}\right)$ \\
Stock Market-PUY, 2008 LMadj & $3.505\left(0.000^{* * *}\right)$ \\
Total Cases-Pesaran and Yamagata (2008) Delta Test $\boldsymbol{\Delta}$ & $0.937(0.174)$ \\
Total Death-Pesaran and Yamagata (2008) Delta Test $\boldsymbol{\Delta}$ & $1.057(0.145)$ \\
Stock Market-Pesaran and Yamagata (2008) Delta Test $\Delta$ & $-1.398(0.919)$ \\
Total Cases-Pesaran and Yamagata (2008) Delta Test $\Delta_{\text {adj }}$ & $1.033(0.151)$ \\
Total Death-Pesaran and Yamagata (2008) Delta Test $\Delta_{\text {adj }}$ & $1.164(0.122)$ \\
Stock Market-Pesaran and Yamagata (2008) Delta Test $\Delta_{\text {adj }}$ & $-1.540(0.938)$ \\
\hline
\end{tabular}

Cross sectional dependency was analyzed with the Pesaran (2004) CDlm test and the Pesaran, Ullah and Yagamata (2008) LMadj tests. The LMadj test used in cases where the $\mathrm{T}$ dimension is larger than the $\mathrm{N}$ dimension, it is observed that the probability values for all variables are less than 0.05 . Therefore, the null hypothesis was rejected which states that there is no cross-sectional dependency between the series. When the results of Pesaran and Yamagata Delta and Delta adj. tests, probability values for both tests were observed to be over the critical level of 0.05 and all variables were homogeneous. 
Table 5. The results of PANIC Unit Root Test

\begin{tabular}{ll}
\hline Total Cases-PANIC Unit Root Test-Constant & $-2.0874(0.981)$ \\
Total Death-PANIC Unit Root Test-Constant & $-1.1592(0.876)$ \\
Stock Market- PANIC Unit Root Test-Constant & $4.8409\left(0.000^{* * *}\right)$ \\
Total Cases-PANIC Unit Root Test-Constant-First Diff. & $1.6754\left(0.046^{* *}\right)$ \\
Total Death-PANIC Unit Root Test-Constant-First Diff. & $2.7043\left(0.003^{* * *}\right)$ \\
Stock Market-PANIC Unit Root Test-Constant-First Diff. & $7.5031\left(0.000^{* * *}\right)$ \\
Total Cases-PANIC Unit Root Test-Constant and Trend & $0.4831(0.314)$ \\
Total Death-PANIC Unit Root Test-Constant and Trend & $1.0723(0.141)$ \\
Stock Market-PANIC Unit Root Test-Constant and Trend & $3.0729\left(0.001^{* * *}\right)$ \\
Total Cases-PANIC Unit Root Test-Constant and Trend-First Diff. & $2.9029\left(0.001^{* * *}\right)$ \\
Total Death-PANIC Unit Root Test-Constant and Trend-First Diff. & $4.2306\left(0.000^{* * *}\right)$ \\
Stock Market-PANIC Unit Root Test-Constant and Trend-First Diff. & $6.3042\left(0.000^{* * *}\right)$ \\
\hline
\end{tabular}

It is seen in Table 5, PANIC unit root test results, it was determined that the series were stationary at their first differences. The probability values of all the variables are significant at levels of $\% 1$ and $\% 5$.

Table 6. The results of F, LM, Honda, Heteroscedasticity and Autocorrelation tests

\begin{tabular}{ll}
\hline F-Group Constant & $0.351(0.955)$ \\
F-Time Constant & $31.001\left(0.000^{* * * *}\right)$ \\
F-Two Way Constant & $19.811\left(0.000^{* * *}\right)$ \\
LM-Group Random & $3.488\left(0.061^{*}\right)$ \\
LM-Time Random & $396.056\left(0.000^{* * *}\right)$ \\
LM-Two Way Random & $399.545\left(0.000^{* * *}\right)$ \\
Honda-Group Random & $-1.867(0.969)$ \\
Honda-Time Random & $19.901\left(0.000^{* * * *}\right)$ \\
Honda-Two Way Random & $12.751\left(0.000^{* * *}\right)$ \\
Breusch-Pagan-Godfrey-LM & $15.386\left(0.081^{*}\right)$ \\
Baltagi and Li (1991)-LM & $5.513\left(0.018^{* *}\right)$ \\
Born and Bretuing (2016)-LM & $10.143\left(0.001^{* * *}\right)$ \\
Durbin-Watson & 2.232 \\
\hline
\end{tabular}

According to the results in the table, F, Breusch-Pagan LM (1980) and Honda (1985) tests were applied to determine which of the fixed effects model, random-effects model and pooled model to use to determine the effect of total number of cases and total number of deaths on stock market return. The results of these tests, it was determined that all probability values for the Breusch-Pagan LM test were less than 0.05 critical value. Therefore, the null hypothesis was rejected for the Breusch-Pagan LM test and it was concluded that using the fixed effects model would efficiency more meaningful results. Also, in the model to be predicted according to the results of the Breusch-Pagan LM test, it was determined that there was only one way time effect.

The heteroscedasticity analyzed with the Breusch-Pagan-Godfrey LM test. According to the test results, the probability value was 0.08 and the null hypothesis cannot be rejected. Therefore, there is no heteroscedasticity. The autocorrelation analyzed with Baltagi and Li (1991) and Born and Bretuing (2016) tests. According to the test results, it was determined that the probability values were less than 0.05 and the null hypothesis was rejected, and autocorrelation problem was found at the model. Durbin Watson test statistic is 2.232 is another indication that there is an autocorrelation problem in the study.

The results in Table 7 indicate that the results of the panel data analysis, which determined the impact of the COVID-19 epidemic on the stock market in Turkey and the 9 most common countries. Estimated model is significant at $1 \%$ and total case and death variables explain 75.7 percent of the changes in stock market return. The result of the research, a positive and significant relationship was found between the stock market return and the total death. The stock market return is influenced by total death (0.04). Increasing the total number of deaths increases the stock market returns. On the other hand, a negative and significant relationship was found between the stock market return and the total cases. The stock market return is influenced by total cases nearly $(0.02)$. Increasing the total number of cases decrease the stock market returns. 
Table 7. Result of panel data analysis

\begin{tabular}{lc}
\hline Variable & Panel-Fixed Effect \\
\hline Constant & $0.0049\left(0.0343^{* *}\right)$ \\
Total Cases & $-0.0432\left(0.0170^{* *}\right)$ \\
Total Death & $0.0416\left(0.0143^{* * *}\right)$ \\
Adjusted R & 0.7577 \\
F-Statistics & 30.260 \\
Probability (F-Statistics) & $0.0000^{* * *}$ \\
Akaike Info Criterion & -5.2903 \\
Schwarz Criterion & -4.9443 \\
Hannan-Quinn Criterion & -5.1498 \\
Dependent Variable & Stock Market \\
Method & Panel Least Squares \\
Sample & $3.18 .2020-4.14 .2020$ \\
Total Panel (Balanced) Observations & 160 \\
\hline
\end{tabular}

\section{Conclusions}

In this study, the relationship between the pandemic and the stock market range of the dates 17-03-2020 and 14-04-2020, when the COVID-19 pandemic was most intense, was examined by panel data analysis method. In this study conducted for Turkey and the 9 countries where the COVID-19 pandemic is most common, COVID-19 data is based on the total number of cases and the total number of deaths, while share market data is based on important stock indexes of countries. Within the scope of the analysis, first of all, Spearman correlation analysis and variance inflation tests were performed to see whether there is a multicollinearity problem between the independent variables. For our study, the cross-sectional dependency was analyzed by Pesaran (2004) CDlm test and Pesaran, Ullah and Yagamata (2008) LMadj tests on a panel and variable basis. Bai and $\mathrm{Ng}$ (2004) PANIC second generation unit root test was used for stationary. F test, Breuch-Pagan LM (1980), Honda (1985) tests were used for the selection of the prediction model. Heteroscedasticity which expresses the problem that the variances of the error terms are not the same for all observations, was analyzed with Breusch-Pagan-Godfrey LM test. Autocorrelation was analyzed with Baltagi and Li (1991), Born and Bretuing (2016) and Bhargava, Franzini and Narendranathan (1982) by the Durbin-Watson tests. Results of the analysis, multicollinearity between independent variables were not found. Cross sectional dependency was determined in the regression model. Accordingly, it was determined that the series are stationary according to the PANIC test results. According to the results of the F test, the model was estimated with one-way fixed effects model. Autocorrelation and heteroscedasticity problems were determined in the fixed effects model. The model was estimated with the White estimator correcting the standard errors in the panel.

The result of the research, a positive and significant relationship was found between the stock market return and the total death. The stock market return is influenced by total death (0.04). Increasing the total number of deaths increases the stock market returns. On the other hand, a negative and significant relationship was found between the stock market return and the total cases. The stock market return is influenced by total cases nearly $(0.02)$. Increasing the total number of cases decrease the stock market returns.

A significant and positive relationship was found between the total deaths due to coronavirus and the stock market return. Accordingly, investors are reducing their demand for stock markets after the deaths due to coronavirus. Thus, the trading volume and closing prices in the stock markets decrease. Investors who buy low-priced securities can also earn high returns. On the other hand, a negative relationship was found between the total number of cases and the share market return. It can be said that investors act behaviorally and do not take into account the total number of cases. Therefore, investors do not avoid from the total case and increase their demand for the stock markets. This situation causes the prices to increase in the stock markets and decreases the stock market return in the following processes.

Investors quickly escape from risky assets in an epidemic environment, natural disaster, war, etc. as with other studies in the literature, it has been proven once again that negative news flow negatively affects share markets. In such cases/events, it is thought that investors should be more cautious. The rate of increase in the total number of cases, the level of the total number of deaths, or the World Health Organization's new explanations related to the COVID-19 outbreak can be a guide for investors. 


\section{References}

Adegun, O. (2014). The effect of ebola virus on the economy of West Africa through the trade channel. Journal of Humanities and Social Sciences, 19(10), 48-56. https://doi.org/10.9790/0837-191044856

Bai, J., \& Ng, S. (2004). A PANIC attack on unit roots and cointegration. Econometrica, 72(4), 1127-1177. https://doi.org/10.1111/j.1468-0262.2004.00528.x

Baker, S. R., Bloom, N., Davis, S. J., Kost, K., Sammon, M., \& Viratyosin, T. (2020). The unprecedented stock market reaction to covid-19. 1 Retrieved from https://insight.kellogg.northwestern.edu/article/what-explains-the-unprecedented-stock-market-reaction-to-c ovid-19

Baltagi, B., \& Li, Q. (1991). A joint test for serial correlation and random individual effects. Statistics and Probability Letters, 11, 277-280. https://doi.org/10.1016/0167-7152(91)90156-L

Bhargava, A., Franzini, L., \& Narendranathan, W. (1982). Serial correlation and the fixed effects model. The Review of Economic Studies, 49(4), 533-549. Retrieved from https://EconPapers.repec.org/RePEc:oup:restud:v:49:y:1982:i:4:p:533-549

Born, B., \& Breitung, J. (2016). Testing for serial correlation in fixed-effects panel data models. Econometric Reviews, 35(7), 1290-1316. Retrieved from: https://www.econstor.eu/handle/10419/37346

Bowles, J., Hjort, J., Melvin, T., \& Werker, E. (2015). Ebola job and economic activity in Liberia. Journal of Epidemiology and Community Health, 70, 271-277. https://doi.org/10.1136/jech-2015-205959

Breusch, T., \& Pagan, A. (1980). The lagrange multiplier test and its applications to model specification in econometrics. Review of Economic Studies, 47(1), 239-253. Retrieved from https://EconPapers.repec.org/RePEc:oup:restud:v:47:y:1980:i:1:p:239-253

Chen, M. H., Jang, S., \& Kim, W. G. (2007). The impact of the sars outbreak on Taiwanese hotel stock performance: An event-study approach. International Journal of Hospitality Management, 26, 200-212. https://doi.org/10.1016/j.ijhm.2005.11.004

Corbet, S., Larkin, C., \& Lucey, B. (2020). The contagion effects of the covld-19 pandemic: Evidence from gold and cryptocurrencies. Retrieved from https://papers.ssrn.com/sol3/papers.cfm?abstract_id=3564443

Fernandes, N. (2020). Economic effects of coronavirus outbreak (COVID-19) on the world economy. Retrieved from https://papers.ssrn.com/sol3/papers.cfm?abstract_id=3557504

FitchRatings Action Report (2020). Fitch Ratings Database [Dataset]. Retrieved from http://www.fitchratings.com

Gupta, A. G., Moyer, C. A., \& Stern, D. T. (2004). The economic impact of quarantine: SARS in Toronto as a case study. Journal of Infection, 50, 386-393. https://doi.org/10.1016/j.jinf.2004.08.006

Hai, W., Zhao, Z., Wang, J., \& Hou, Z. G. (2004). The short-term impact of SARS on the Chinese economy. Asian Economic Paper, 3(1), 57-61. https://doi.org/10.1162/1535351041747905

Honda, Y. (1985). Testing the error components model with non-normal disturbances. Review of Economic Studies, 52, 681-690. https://doi.org/10.2307/2297739

International Monetary Fund. (2020). World Economic Outlook Database [Dataset]. Retrieved from http://www.imf.org

Kongoley, P. S. (2015). The impact of Ebola on the tourism and hospitality industry in Sierra Leone. International Journal of Scientific and Research Publications, 5(12), 542-550. Retrieved from http://www.ijsrp.org

Loh, E. (2006). The impact of SARS on the performance and risk profile of airline stocks. International Journal of Transport Economics, 33(3), 401-422. Retrieved from https://www.jstor.org/stable/42747811

Marinc, R. I. M. (2016). Geographic proximity of information to financial markets and impact on stock prices: Evidence from the Ebola outbreak. International Conference on Management Business and Economics, Retrieved from https://knowledgecenter.ubt-uni.net/conference

Marley, C. T., Levsky, M. E., Talbot, T. S., \& Kang, C. S. (2004). Sars and it's impact on current and future emergency department operations. The Journal of Emergency Medicine, 26(4), 415-420. https://doi.org/10.1016/j.jemermed.2003.12.023 
Masson, P. (1998). Contagion: Monsoonal effects spillover and jumps between multiple equilibria. International Monetary Fund Working Paper Database [Dataset]. Retrieved from http://www.imf.org

Moody's Investors Service. (2020). Reports Database [Rating Action Dataset]. Retrieved from http://www.moodys.com

Onali, E. (2020). Covid-19 and stock market volatility. https://doi.org/10.2139/ssrn.3571453

Organization for Economic Co-operation and Development. (2020). Interim Economic Outlook Database [Dataset]. Retrieved from http://www.oecd.org

Pesaran, H., \& Yamagata, T. (2008). Testing slope homogeneity in large panels. Journal of Econometrics, 142, 50-93. Retrieved from https:/EconPapers.repec.org/RePEc:eee:econom:v:142:y:2008:i:1:p:50-93

Pesaran, M. H., Ullah, A., \& Yamagata, T. (2008). A bias-adjusted $1 \mathrm{~m}$ test of error cross-section independence. $\begin{array}{lllll}\text { Econometrics } & \text { Journal, } & \text { Retrieved } & \text { from }\end{array}$ https://EconPapers.repec.org/RePEc:ect:emjrnl:v:11:y:2008:i:1:p:105-127

Ramelli, S., \&Wagner, A. F. (2020). Feverish stock price reactions to COVID-19. The Review of Corporate Finance Studies. https://doi.org/10.1093/rcfs/cfaa012

United States Department of Labor. (2020). Employment and Unemployment Database [Dataset]. Retrieved from http://www.dol.gov

World Health Organization. (2020). COVID-19 Situation Report Database [Dataset]. Retrieved from http://www.who.int

Zeren, F., \& Hizarc1, A. (2020). The impact of covid-19 coronavirus on stock markets: Evidence from selected countries. Muhasebe ve Finansman Inceleme Dergisi, 3(1), 78-84. https://doi.org/10.32951/mufider.706159

\section{Copyrights}

Copyright for this article is retained by the author(s), with first publication rights granted to the journal.

This is an open-access article distributed under the terms and conditions of the Creative Commons Attribution license (http://creativecommons.org/licenses/by/4.0/). 